\title{
Banking Sector Globalization and Monetary Policy Transmission: Evidence from Asian Countries
}

September 21, 2018

\begin{abstract}
Cetorelli and Goldberg (2012a) have shown that U.S. global banks (those with foreign subsidiaries) can smooth the effects of monetary policy tightening on their lending through drawing on subsidiary resources, giving a hampering of policy transmission. In panel data for Asian banks we find strong evidence of the hampering of policy transmission to interest rates on bank loans, and weaker evidence of hampering in transmission to lending quantities. We also present evidence that lending within global banks is consistent with the internal capital markets hypothesis that underpins reduced transmission of monetary policy in a globalized banking system.
\end{abstract}

Keywords: Global banks, monetary policy transmission, bank lending channel, panel data

JEL Codes: E44, E50, F34 


\section{Introduction}

Globalization of the banking sectors in Asian countries has gathered pace in recent decades. In addition to the emergence of foreign-owned banks as significant lenders in Asian markets, the data show that large numbers of domestically head-quartered banks are global in the sense that they have foreign subsidiaries with whom they may operate internal markets for capital and liquidity. Cetorelli and Goldberg (2012a) have argued that such global banks, when facing financial stress in their domestic market, reallocate funding from foreign subsidiaries in order to smooth domestic lending. As a result, monetary policy transmission via the bank lending channel in domestic markets will be hampered when a large share of domestic banks are global operators with foreign subsidiaries. In this paper we study banks that are head-quartered in one of eight Asian countries, but that have subsidiary operations in other countries, and present evidence of weaker transmission of monetary policy to both the lending volumes and lending interest rates of such banks when compared to domestic banks without significant foreign subsidiary interests. As such, there is hampering of monetary policy transmission to global banks. The economic and statistical significance of the hampering effect is greatest amongst those global banks with the largest foreign subsidiaries who can access the largest internal capital markets.

In our dataset we consider 271 commercial banks in eight Asian countries: Hong Kong, Indonesia, Korea, Malaysia, the Philippines, Singapore, Taiwan and Thailand. Amongst the domestically-owned and head-quartered banks we define a Global bank as one that has at least one foreign subsidiary abroad for which the bank in question has a $50 \%$ or higher equity stake. Hereafter, we term global banks head-quartered in the eight selected Asian countries as Parents, whilst banks head-quartered in the Asian countries we consider without controlling interests in international subsidiaries are Domestic Banks. A bank operating in a particular market is defined as a Foreign bank if $50 \%$ or more of its capital is owned by banks or firms head-quartered outside that market; this is the category of banks operating in Asia studied by Jeon and $\mathrm{Wu}$ (2014). These authors find that foreign banks operating in seven Asian countries reduced their bank lending significantly relative to domestic banks during the financial crisis period. Jeon and $\mathrm{Wu}$ postulate that this is due to the reallocation of funds from foreign banks (subsidiaries) to their head offices through internal capital markets. These authors provide the first evidence of the impact of banking sector globalization on monetary transmission in Asia. The contribution of our study is to set out evidence of a separate dimension to banking sector globalization and its impact on monetary policy transmission. As we document in Section 3 , global banks (in our terminology, Parents) have grown in importance relative to foreign banks 
since 2000 and, measured in terms of asset share, now represent the most important international linkage in the Asian banking system. Our results point to reduced monetary transmission to this important class of banks, and we provide supplementary evidence that the operation of internal capital markets accounts for this hampering effect. As such, our results suggest that the importance of banking sector globalization for understanding monetary transmission in Asia extends beyonds the behaviour of foreign-owned banks, and may be much greater than hitherto believed.

One possible concern with the results that we present is selection bias. It might be the case that the largest and most successful banks tend to become global banks (Parents) by launching new subsidiaries abroad and, at the same time, are better able to deal with financial stress by accessing external funds. If this is the case, the hampering effect that we document (Parents being less responsive to monetary policy) may just reflect the size/success of banks we classify as Parents, and not any intrinsic feature of globalized banking structures linked to internal capital markets. To address this concern, we control for the effects of other bank characteristics on the strength of monetary transmission, including size, liquidity and capital positions.

We present two further sets of results. Firstly, we allow for different lending responses to monetary policy during the 2008-2009 financial crisis. We find that during the crisis a tightening of lending occurred amongst domestic banks despite the easing of monetary policy, so that during these two years the basic effect of monetary policy on bank lending is of unexpected sign. This effect is strongest for the group of foreign-owned banks, as shown previously by Jeon and $\mathrm{Wu}(2014)$, which fits with the fact that these banks are often owned by North American and European banks, which were those most affected by the global financial crisis. We also show that during the crisis years the tightening of bank lending was not observed amongst the global (Asian owned) banks with access to greatest foreign subsidiary resources. One interpretation is that deteriorating financial conditions forced a lending reversal for domestic banks whilst monetary policy was being eased, but this effect was less pronounced amongst global banks who could draw on subsidiary resources to stabilize their lending.

Secondly, in Section 5.2, we investigate the relationship between the bank lending of foreign subsidiaries, or Juniors, and their Parents' financial conditions, following the strategies adopted in Jeon et al. (2013). The primary idea is that the connection between the loan growth of Juniors and the financial conditions of their Parents can be regarded as evidence of internal capital markets linking Parents and Juniors. Using this approach, we find that when Parents are in a better financial condition, their Juniors become less dependent on their own internal funds in expanding lending, and vice versa, though the evidence is weak. Nevertheless, we 
consider this evidence to be consistent with the claim that internal capital markets contribute to the hampering of monetary policy amongst global banks that we estimate in our core results.

The remainder of this paper proceeds as follows. In Section 2, we discuss existing research concerning the links between banking sector globalization and monetary transmission. Section 3 investigates the structure of the banking industry in our sample of Asian countries, with particularly reference to global banks. In Section 4, we explain the construction of the dataset and in Section 5 we present our empirical results and robustness exercises. Section 6 concludes.

\section{Relevant studies}

In this section we briefly review existing literature on the impact of banking sector globalization on the strength of monetary policy transmission. We start with an outline of seminal work in this area carried out for the United States and then summarise recent work covering Asian countries.

US evidence Using US bank-level regulatory data from 1980 to 2005, Cetorelli and Goldberg (2012a) found that having global operations reduces the sensitivity of bank lending to monetary policy. Controlling for this relationship also revealed that banks without global operations are affected by US monetary policy to a larger extent than previously found. They also found evidence that the internal capital market between the head offices and their foreign subsidiaries plays a role, by examining the internal transactions between them. In a separate study, Cetorelli and Goldberg (2012c) showed that parent banks, when hit by a funding shock, reallocate liquidity in the organization according to a locational pecking order. Affiliate locations that are important for the parent bank revenue streams are relatively protected from the liquidity reallocations in the organization. Cetorelli and Goldberg (2012b) analysed the activity of foreign banks in the US. They found that internal capital markets are at play in response to parent-bank funding shocks, and this causes a sizeable impact on the branch lending supply in the US. In related work Correa, Goldberg and Rice (2014) found that the intra-firm borrowing in US global banks resulting from liquidity management strategies across organization as a whole serves as a shock absorber and affects lending to domestic and foreign customers. Using micro-data on global banks with branch operations in the US, Cetorelli and Goldberg (2016) found that branches of conglomerates in more complex families have a markedly lower lending sensitivity to funding shocks. They report the complexity of the conglomerate can change the scale of the lending channel for a large global bank by more than 30 percent. 
Non-US evidence The literature on non-US countries mainly focuses on the impact of foreign ownership of domestic banks on monetary transmission, rather than the consequences of domestic banks acquiring foreign subsidiaries with whom they can exchange funding to smooth the effects of monetary policy on access to finance. Cetorelli and Goldberg (2011) analysed a matrix of bank lending between 17 developed source and 94 emerging market destination countries across Asia, Latin America,and Europe from 2007 to 2009, and found that loan supply in emerging markets could be significantly affected through three separate channels linked to the foreign bank operations: a contraction in direct, cross-border lending by foreign banks; a contraction in local lending by foreign banks affiliates; and a contraction in lending by domestic banks resulting from reduced funding after a decline in interbank, cross-border lending.

Examining emerging economies data from Asia, Latin America, and Central and Eastern Europe during the period from 1996 to 2003, Wu, Luca and Jeon (2011) found that the bank lending channel has declined in strength as a result of foreign banks entering those markets. They suggested the access of foreign banks to funding from parent banks through internal capital markets as the most convincing explanation. Jeon and Wu (2014) studied bank lending for seven Asian countries, focusing on foreign-owned banks during the recent financial crisis period. They incorporate two dummy variables into a standard bank lending regression, one to distinguish foreign banks from domestic banks, and one for the 2008-2009 financial crisis period. They found that foreign banks reduced their lending significantly during the crisis period and postulate that this is due to the reallocation of funds from foreign banks (subsidiaries) to their head offices via internal capital markets. In an earlier study, Jeon, Olivero and Wu (2013) attempted to find more direct evidence supporting the existence of internal capital markets using bank-level data for 368 foreign subsidiaries of 68 multinational banks in 47 emerging economies during the period 1994-2008. They measured how parent banks' financial conditions affects their subsidiaries' dependence on their own funds in expanding loan growth, and found that when parent banks (head offices) are in a good financial condition, loan growth of subsidiaries becomes less dependent on their own funds.

Our regression specifications broadly follow those of Jeon et al. (2013) and Jeon and Wu (2014). The primary difference to Jeon and $\mathrm{Wu}$ (2014) is that we concentrate on domesticallyowned global banks (Parents) and their impact on monetary policy transmission. As we argue in the next section, these banks have now overtaken foreign-owned banks in terms of total assets in a number of Asian economies and their behaviour is therefore important for the operation of the financial system across Asia. 


\section{The structure of the banking industry in Asia}

In this section we examine the primary features of Parents (global banks head-quartered in Asian countries) and investigate the relative size of their Juniors (foreign subsidiaries affiliated with Parents). The figures in this section were constructed based on the annual bank-level data for of 271 commercial banks from eight selected Asian countries in BankScope. The banks are observed over the period 2000-2014.

\subsection{Banking industry structure and global banks}

The most salient feature of the banking structures of the eight Asian countries that we consider is a high level of concentration. Table 1 shows that the largest $10 \%$ of banks account for between one third and two thirds of total bank assets in a country. The largest $50 \%$ of banks account for almost $90 \%$ of total assets.

Table 1: Concentration of the banking industry

\begin{tabular}{|c|c|c|c|c|}
\hline & \multirow{2}{*}{$\mathrm{HHI}^{1)}$} & \multicolumn{3}{|c|}{$\underline{\text { Share of Asset }}{ }^{2)}$} \\
\hline & & 10 th & 25 th & 50 th \\
\hline Hong Kong & 0.258 & 77.3 & 88.8 & 98.1 \\
\hline Indonesia & 0.085 & 63.0 & 81.2 & 93.5 \\
\hline Korea & 0.125 & 35.6 & 63.4 & 90.0 \\
\hline Malaysia & 0.102 & 47.5 & 68.2 & 91.0 \\
\hline Philippines & 0.104 & 46.8 & 69.2 & 91.8 \\
\hline Singapore & 0.315 & 40.8 & 94.8 & 97.9 \\
\hline Taiwan & 0.111 & 33.7 & 68.1 & 90.4 \\
\hline Thailand & 0.053 & 33.4 & 63.7 & 86.2 \\
\hline \multicolumn{5}{|c|}{$\begin{array}{l}\text { Notes: 1) Herfindahl-Hirschman Index: } H H I=\sum_{i=1}^{N} s_{i}^{2} \text { where, } \\
i \text { is market share of bank } i \text { operating in the country }\left(s_{i}=\right. \\
\left.\text { sset }_{i} / \sum_{i=1}^{N} \text { asset }_{i}\right), 2 \text { ) Asset share of the largest 10th, 25th, 50th per- } \\
\text { entile banks in size in each domestic banking sector, 3) As of } 2010\end{array}$} \\
\hline
\end{tabular}

To investigate banking structure in detail, we classify 271 commercial banks operating in the eight Asian countries based on their ownership type. Domestically-owned banks are classified as either global banks or domestic banks, based on whether they have at least one foreign subsidiary. Foreign banks are foreign-owned banks operating in the region. For the banks operating in the eight Asian countries, we term global banks as Parents, the foreign banks as Foreign banks, and the domestic banks as Domestic banks.

Using this classification, Table 2 shows the composition of the banking sector in numbers, total assets, and average assets per bank in the years 2000 and 2010. The high degree of 
- Global bank: A domestically-owned bank that has at least one foreign subsidiary abroad for which the head office has $50 \%$ or higher controlling equity

- Foreign bank: A bank owned by foreign banks or firms; the capital owned by overseas banks or firms is higher than $50 \%$ of the capital

- Domestic bank: A domestically-owned bank that does not have a foreign subsidiary abroad

concentration in the banking sector, as illustrated in Table 1, is driven by the Parents, as the Parents constitute the largest banks in each country. In 2010, the Parents in the eight countries accounted for 26 out of 212 banks (12.3\%), but $41.2 \%$ of total assets. The average assets of the Parents is 83.4 billion US dollars, far exceeding those of the Domestic banks (13.5 billion US\$) and the Foreign banks (20.8 billion US\$).

This contrast becomes more enlarged when we exclude Hong Kong, where Foreign banks, not Parents, constitute the largest bank group, possibly due to its historical background 1 With Hong Kong excluded, in 201024 Parents (13.3\%) account for 53.7\% of total assets, while 57 Foreign banks (31.5\%) take up $10.1 \%$ of assets. It is also clear that from 2000 to 2010, the difference in asset shares between Parents and Foreign banks increased. Given the importance of Parents in the Asian banking system, we consider the possibility that the behaviour of these banks plays a key role in the impact of financial sector globalization on monetary policy transmission.

\subsection{Global banks and their foreign subsidiaries}

In this section we consider the relationships between banks in our sample in more detail. Figure 1 illustrates the composition of the banking sector by type of ownership. In the eight countries in our sample there exist 26 Parents, 157 Domestic banks and 113 Foreign banks. Note that these figures sum to more than the total of 271 banks that we consider because some of those 271 banks change status during the sample and therefore appear twice in the classifications.

If we shift our focus to right-handside of Figure 1, 26 Parents have 82 Juniors (foreign subsidiaries). Each Parent has 3.2 Juniors on average, with the range being 1 to 7 ; these Juniors are located in 19 countries ${ }^{2}$ Note that 30 of the 82 Juniors are located in the eight Asian

\footnotetext{
${ }^{1}$ Hong Kong has a high penetration of foreign banks, both in number of banks and in assets; only one domestic bank was ranked as one of the largest 10 banks. In Hong Kong, the largest banks are either UK or China originated foreign banks.

${ }^{2}$ By region, the majority of subsidiaries (63 out of 82) are located in other Asian countries, while 8 and 1 are located in the European Union (EU) and the US, respectively.
} 
Table 2: Structure of the banking industry

\begin{tabular}{lrrrr}
\hline \hline & \multicolumn{2}{c}{ All countries ${ }^{1)}$} & \multicolumn{2}{c}{ Excluding HK ${ }^{2)}$} \\
\cline { 5 - 6 } \cline { 5 - 5 } & 2000 & 2010 & 2000 & 2010 \\
\hline Number of banks & & & & \\
Parents & 18 & 26 & 16 & 24 \\
Domestic bank & 133 & 105 & 125 & 100 \\
Foreign bank & 85 & 81 & 52 & 57 \\
All banks & 236 & 212 & 193 & 181 \\
& & & & \\
Share of assets (\%) & & & & \\
Parents & 25.0 & 41.2 & 32.2 & 53.7 \\
Domestic bank & 46.9 & 26.8 & 62.7 & 36.1 \\
Foreign bank & 28.0 & 31.9 & 5.2 & 10.1 \\
All banks & 100.0 & 100.0 & 100.0 & 100.0 \\
& & & & \\
Asset per bank & & & & \\
Parents & & & & \\
Domestic bank & 27.8 & 83.4 & 29.5 & 86.8 \\
Foreign bank & 7.1 & 13.5 & 7.3 & 14.0 \\
All banks & 6.6 & 20.8 & 1.5 & 6.9 \\
\hline
\end{tabular}

Notes: 1) Include all the eight selected Asian countries,

2) Seven countries with Hong Kong excluded, 3) billion US\$,

4) See online APPENDIX II for detailed information on banking industry structure by country and by year.

countries in our sample $3^{3}$ and are therefore part of the set of 113 Foreign banks (this overlap does not create any issues in our empirical work because, as we explain in Section 5, none of our investigations require a comparison of Foreign banks and Juniors).

\footnotetext{
${ }^{3}$ The other 33 Juniors located in Asia are mainly located in China and the southern Asian countries of Vietnam and Cambodia.
} 
Figure 1: Composition of the banks based on their type of ownership

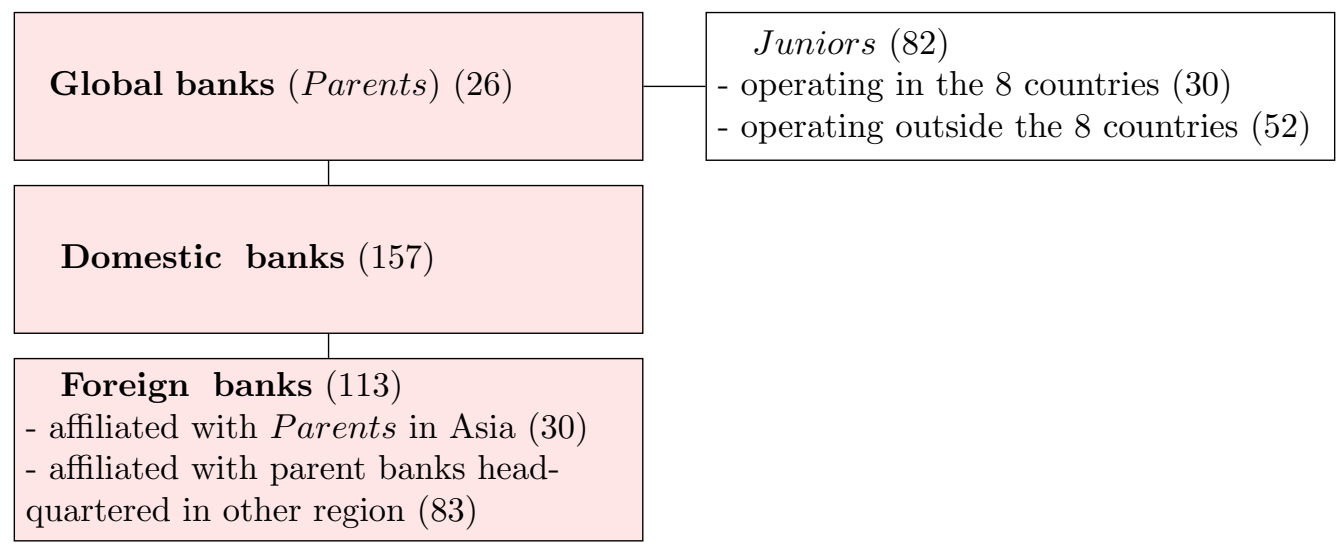

This diagram illustrates the scope of banks used in our analysis based on their type of ownerships. One dataset examines 271 banks operating in the 8 selected Asia countries, while the second dataset investigates 26 Parents banks and their 82 Juniors. Figures in parenthesis is the number of banks.

- Banks in the 8 countries: 271 commercial banks in the eight Asian countries (shaded area) constitute the first dataset used Section 5.1. We categorize these 271 banks based on the type of ownership into Parents (global banks), Domestic (domestically-owned banks that do not have a foreign subsidiary) and Foreign bank (foreign-owned banks). One caveat is that sum of the number of banks in each of the sub-categories exceeds total number of banks (271), reflecting that some of the banks experienced a change in type during 2000-2014.

- 26 Parents and their 82 Juniors: In Section 5.2, we build upon the second dataset. This dataset consists of the 26 Parents and their 82 Juniors (foreign subsidiaries affiliated with the 26 Parents) operating in 19 countries. One caveat is that 30 out of these 82 Juniors are located in one of the 8 Asian countries (but not the country where its Parents are located). Thus, they are included in both datasets (classified as Foreign bank in the first dataset).

Relative size of the subsidiaries An important feature of the Juniors is their size. This is because the larger the Juniors the more funding Parents may extract from them to offset the effects of higher domestic funding costs that they face after a monetary policy tightening. Figure 2 delivers information on the relative size of Juniors, as compared to their Parent. At first, Panel A provides the distribution of the relative size of the Juniors based on 739 bankyear observations from 2000 to 2014. The x-axis represents the relative size of a single Junior relative to its Parent in each year $\left(=\right.$ asset $_{j}^{J} /$ asset $\left._{i}^{P} \times 100\right)$. The y-axis represents frequency. The distribution of the Juniors size is very left-skewed, with its median $1.31 \%$ and mean $7.38 \%$ (Std Dev. 13.88\%). This illustrates that an individual subsidiary is quite small, when compared to its parent banks.

Secondly, we sum the size of the individual subsidiaries in Panel A across Parent, to calculate the total size of all subsidiaries of each Parent in a specific year $\left(=\sum_{j=1}^{n}\right.$ asset $_{j}^{J} /$ asset $\left._{i}^{P} \times 100\right)$. Panel B shows the distribution of this aggregated size, based on 326 bank-year observations from 2000 to 2014. The $\mathrm{x}$-axis represents the ratio and the y-axis represents the frequency. 
This distribution is left-skewed as well, with its median being $1.99 \%$ and the mean $16.00 \%$ (Std Dev. 24.70\%). In Section 5.2, we divide Parents into two sub-groups based on these statistics; (i) Parents ${ }^{(1)}$ that have Juniors with relatively large total assets and (ii) Parents ${ }^{(2)}$ that have Juniors with relatively small total assets (we expect a stronger hampering of monetary policy amongst the Parents $^{(1)}$ group that can access greater subsidiary resources).

Figure 2: Division of Parents, based on the size of their Juniors
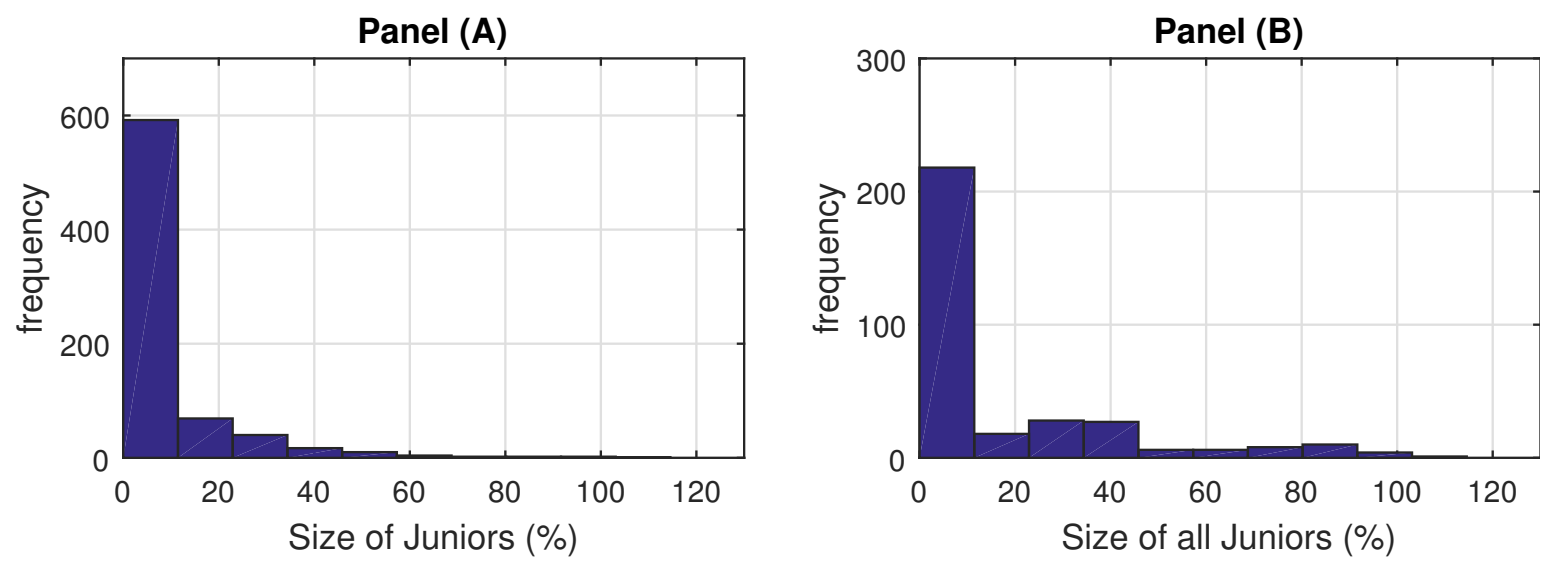

Notes: 1) In Panel (A) presents distribution of Juniors in its size. The x-axis represents the ratio of a single Juniors assets to its Parents assets for a specific year $\left(=\right.$ asset $_{j}^{J} /$ asset $\left._{i}^{P} \times 100\right)$. The y-axis represents its frequency based on 739 bank-year observations from 2000 to 2014 (Median 1.31\%, Mean 7.38\%, Std Dev. 13.88, Min $0.00 \%$, Max 114.57\%).

2) Panel (B) presents distribution of the Parents by the total assets of all the Juniors that they have. The $\mathrm{x}$-axis denotes the ratio of total assets of all Juniors affiliated to each Parents $\left(=\sum_{j=1}^{n}\right.$ asset $_{j}^{J} /$ asset $\left._{i}^{P} \times 100\right)$ based on 326 bank-year observations from 2000 to 2014 (Median 1.99\%, Mean 16.00\%, Std Dev. 24.70, Min $0.00 \%$, Max $114.57 \%)$.

\section{Data description}

In this section we briefly introduce the standard model typically adopted to investigate the bank lending channel and what kind of indicators are included in the estimation of such a model. Then we explain how to construct the bank-level and country-level dataset that will be used in our empirical analysis. Our regression specifications will be explained in more detail in Section 5.

\subsection{Bank-level data}

We used Bureau van Dijk's BankScope database to construct the annual unbalanced panel data for bank lending and bank characteristics. BankScope provides information from individual bank balance sheets and financial statements in a standard format. We only include commercial banks to exclude the possible bias due to the different nature and business scope of 
the different types of banks 4

The definitions of the bank-level variables (two dependent variables and five bank characteristics) used are as follows (See online APPENDIX I for more detail). We consider two dependent variables, real loan growth rate and real loan interest rate, representing a change in the loan quantity and a change in loan price in real terms, respectively. For the bank characteristic variables, we include five indicators that measure the size of liquid assets, equity and total assets, and the degree of riskiness and the level of profitability of the bank loan book.

Dependent variables (bank lending):

- Real loan growth rate (\%) : a change in the loan quantity in real terms, $(\Delta \ln \operatorname{Loan})$ generated by deflating nominal loan in the local currency with the domestic price level (CPI).

- Real loan interest rate $(\% \mathrm{p}) \quad$ : a measure of a change in the loan price, which $(\Delta$ Loan rate) is the difference in the ratio of the interest income to the total earning assets.

Bank characteristics variables:

- Liquidity (\%)

: a ratio of liquid assets to total assets.

- Capitalization (\%)

- Size $(\log )$

- Riskiness (\%)

- Profitability (\%)

: a ratio of equity to total assets.

: a log of the total assets measured in US dollars.

: a ratio of the loan loss provision to total loans.

: a ratio of the net income to total assets (ROAA).

Note: See online APPENDIX I for definitions of each of these variables in detail.

To eliminate the impacts of abnormal observations, we excluded the highest and lowest $1 \%$ of the growth rates of the assets and loans in real terms (this removes cases of very rapid asset growth due to mergers and similar events). We also excluded the highest and lowest $1 \%$ of banks by liquidity, capitalization and riskiness. After this procedure was conducted, we had an unbalanced dataset, consisting of 2,613 bank-year observations for 271 banks with 314 bankyear observations removed. In order to show that our results do not depend on these steps we report results without outlier exclusions in Section 5.3.

Table 3 illustrates the descriptive statistics of the bank lending variables and the bank characteristics by bank type group. Compared to the other types of banks, Parents have less liquid assets and equity, measured as a ratio to total assets. In size, measured in terms of assets, Parents are the largest, followed by the Domestic banks and Foreign banks. These

\footnotetext{
${ }^{4}$ BankScope classifies banks into 6 categories, based on specialization (except central banks): commercial banks, saving banks, cooperative banks, real estate and mortgage banks, investment banks and Islamic banks. As of 2014 , commercial banks constituted $58.7 \%$ in number (283 out of 482 banks), and $88.1 \%$ in total assets ( 7.6 out of 8.6 trillion US\$).
} 
characteristics of Parents, as compared to Domestic banks and Foreign banks, necessitate controlling for these factors to partial out the effects of these bank characteristics on bank lending.

In addition, we examine the correlation structure among the bank-level variables (the pairwise correlation matrix in online APPENDIX III). If some of the bank characteristics are highly correlated and included in the estimation model simultaneously, this might generate a problem of multicollinearity. We confirm that some of the bank characteristics are statistically significantly correlated; however, they do not have large correlation coefficients.

Table 3: Descriptive statistics

\begin{tabular}{lrrrr}
\hline \hline \multirow{2}{*}{ Type of Banks } & $\begin{array}{r}\text { All } \\
\text { banks }\end{array}$ & $\begin{array}{r}\text { Parents } \\
\text { banks }\end{array}$ & $\begin{array}{r}\text { Domestic } \\
\text { banks }\end{array}$ & $\begin{array}{r}\text { Foreign } \\
\text { banks }\end{array}$ \\
\hline Observations & 2,613 & 319 & 1,392 & 902 \\
Groups $^{2)}$ & 271 & 26 & 157 & 113 \\
\hline$\Delta$ lnAsset $^{3)}(\%)$ & 6.99 & 7.10 & 7.11 & 6.78 \\
$\Delta$ lnLoan (\%) & 8.22 & 8.56 & 8.05 & 8.35 \\
$\Delta$ Loan rate (\% point) & -0.31 & -0.28 & -0.27 & -0.39 \\
Liquidity (\%) & 22.01 & 17.89 & 19.32 & 27.61 \\
Capitalization (\%) & 11.24 & 8.47 & 10.00 & 14.12 \\
Size (log) $_{\text {Riskiness (\%) }}$ & 8.50 & 10.67 & 8.40 & 7.90 \\
ROAA (\%) & 1.05 & 1.09 & 1.13 & 0.91 \\
\hline
\end{tabular}

Notes: 1) Figures are mean value of total 2,613 bank-year observations. 2) Number of sub-groups exceeds total number reflecting that some banks experience a change of type of bank ownership during 2000 to 2014. 3) As size is dummy variable, there cannot be any size outliers. Instead we exclude outliers relevant to size based on growth rates of real assets $(\Delta \ln A s s e t)$. This is because we do not regard the largest and the smallest banks as outliers, rather we regard a significant change in asset size as abnormal observations possibly stemming from managerial changes such as M\&A (mergers and acquisitions). 4) See online APPENDIX III for further information on descriptive statistics and pair-wise correlation coefficients.

\subsection{Country-level data}

The country-specific data consist of indicators representing monetary policy, overall economic activity and banking sector structure. For an indicator of monetary policy, we use the annual change in the overnight interbank loan rate. Since this is the main measure of the price of short term funds for banks it should capture the monetary policy stance regardless of the precise monetary policy operating procedure that each country adopts. Among the total 2,613 bank-year observations from 2000 to 2014, 1,135 observations were related to policy tightening $(M P>0)$, while 1,413 corresponded to policy easing $(M P<0)$. For 65 observations monetary 
policy is unchanged $(M P=0)$.

An important issue in the measurement of monetary policy in our sample is that in both Hong Kong and Singapore monetary policy is subordinated to the maintenance of an exchange rate peg versus the US dollar 5 In effect there is no independent monetary policy in these two countries, so all variations in monetary policy conditions arise from the respective central banks replicating the monetary policy decisions of the United States. If the exchange rate pegs were defended purely through varying local interest rates in line with the federal funds rate then our approach would not be problematic, in that the local interest rate would be the definitive measure of monetary policy and there would be a unique source of changes to monetary policy, namely policy changes in the United States. In order to investigate this issue we consulted two sources describing the conduct of monetary policy in Hong Kong and Singapore respectively: Annual Report 2016 (Hong Kong Monetary Authority 2017) and Monetary Policy Operations in Singapore (Monetary Authority of Singapore 2013). These sources indicate that exchange rate parities are maintained through a combination of local interest rate changes (to mimic those of the United States) and, when necessary, support buying/selling of the local currency on foreign exchange markets. It is therefore possible that our policy measure (local inter-bank interest rate changes) misses some policy changes for Hong Kong and Singapore, e.g. local interest rates could stay the same but monetary policy is tightened through the use of foreign exchange reserves for support buying of the currency that takes some local currency out of circulation and constitutes a quantitative tightening of policy. An important caveat, then, in interpreting our results is that any heterogeneous effects of monetary policy exist only for the sub-set of monetary policy changes implemented via changes to interest rates, not to those occurring via quantitative interventions in the foreign exchange market. One further point to note is that our reading of Annual Report (2016) of Hong Kong Monetary Authority, indicates that when the Hong Kong Monetary Authority uses interest rates to defend the currency it effects base rate changes which are highly correlated with but need not be identical to the overnight interbank rate. To investigate this issue we re-ran our core regressions, to be presented in Tables 5 and 6, after using base rate changes for Hong Kong. The results are presented in the online APPENDIX V. These results show that whilst the statistical significance of our main findings is reduced slightly, qualitatively they remain intact.

As measures of overall economic activity in the country the growth rate of real GDP and the unemployment rate are adopted. For indicators of banking sector conditions, the financial depth and HHI (Herfindal-Hirschman index) are included ${ }^{6}$ Financial depth, a measure of financial

\footnotetext{
${ }^{5}$ We are grateful to an anonymous referee for forcing our attention to this issue.

${ }^{6}$ Though these are not indicators that are commonly included in the relevant literature, we include these
} 
resources provided to the private sector, is measured as the ratio of bank credit to the private sector to GDP. The degree of concentration, and thus, competition in the banking sector is measured by the HHI, calculated as the sum of the squares of each bank's share of assets in the banking sector of the countries considered. We calculate this index using the bank-level data from BankScope. The macroeconomic conditions and banking sector indicators for the eight countries were collected from the International Financial Statistics (IFS) of the International Monetary Fund (IMF), except for financial depth, which was provided by the World Bank database.

\section{Identification strategies and estimation results}

This section consists of three sub-sections. In Section 5.1 we compare the responsiveness of bank lending and bank interest rates to monetary policy amongst different types of banks. In Section 5.2 we present supplementary evidence for the existence of internal capital markets within Asian banking networks through examining whether the financial condition of Parents affects the loan growth of their Juniors, and vice versa. We provide robustness test results in Section 5.3

\subsection{Hampering effect of global banks on monetary policy}

\subsubsection{Identification model}

We use Equation (1) to measure the response to monetary policy of Asia head-quartered global banks relative to domestic banks. The main difference from a general model for bank lending channel is that we introduce the dummy variable Parents $_{i j t}$, indicating the type of bank ownership and its interaction terms with the monetary policy indicator.

$$
\begin{aligned}
\text { Lending }_{i j t} & =\beta_{0}+\beta_{1} M P_{j t}+\beta_{2} \text { Crisis }+\beta_{3}\left(M P_{j t} \times \text { Crisis }\right)+\beta_{4}^{(k)} \text { Parents }_{i j t}^{(k)} \\
& +\beta_{5}^{(k)}\left(\text { Parents }_{i j t}^{(k)} \times M P_{j t}\right)+\beta_{6}^{(k)}\left(\text { Parents }_{i j t}^{(k)} \times M P_{j t} \times \text { Crisis }\right) \\
& +\beta_{7} \text { BankChar }_{i j t-1}+\beta_{8} \text { Macro }_{j t}+\beta_{9} \text { BankSec }_{j t}+\text { bank }_{i}+\epsilon_{i j t}
\end{aligned}
$$

where,

In Equation (1), $k=\{1,2\}$ indicates the group of Parents, either Parents ${ }^{(1)}$ or Parents ${ }^{(2)}$.

variables because the overall availability of bank credit and competition in the banking sector might affect the bank loan supply, following Jeon and $\mathrm{Wu}$ (2014). We also examine the estimation results without these variables and find that the main results do not change. 
- Lending $\quad$ : bank lending, $\Delta \operatorname{lnLoan}_{i j t}$ (for quantity), $\Delta$ Loan rate (for price)

- MP : monetary policy indicator, $\Delta$ Money market rate r $_{j t}$

- Parents : dummy variable indicating Parents (Global banks head-quartered in the eight Asia countries)

- BankChar : bank characteristics, [Capitalization, Liquidity, Size, Riskiness, Profitability]

- Macro : macroeconomic conditions, [real growth rate, unemployment rate $]$

- BankSec : banking sector environment, [Financial depth, HHI].

Subscript $i$ denotes an individual bank, $j$ denotes one of the eight countries where the banks operate, and $t$ denotes the specific year. The dependent variable, Lending ${ }_{i j t}$, represents a change in the bank lending of bank $i$ in country $j$ in year $t$. We adopt two different measures for Lending $_{i j t}$ : (1) a change in the quantity of the loans $\left(\Delta \operatorname{lnLoan}_{i j t}\right)$, denoting the growth rate of a bank loan in real terms, and (2) a change in the interest rates that banks charge on their loans $(\Delta$ Loan rate rjt $)$, standing for a change in the loan interest rate.

$M P_{j t}$ denotes the monetary policy of country $j$ in year $t$, measured by the annual difference of the overnight interbank loan rate. A positive (negative) value of $M P_{j t}$ represents a tightening (easing) of monetary policy.

Parents $^{(1)}$ is a dummy variable set to one for Parents with relatively larger Juniors, and Parents $^{(2)}$ is a dummy variable set to one for Parents with relatively smaller Juniors. To implement the split by size of Juniors we use the median value of the ratio of total assets of all Juniors affiliated to a particular Parent to the total assets of the Parent. We expect stronger hampering effects for the group of Parents able to access proportionately larger amounts of foreign subsidiary resources. For a bank that experienced a change of ownership during the period, different types are applied for different time periods. To identify the bank type in each period, we utilize the relevant information from BankScope, annual reports and the bank history. The list of Parents and the relevant information on them in our selected economies is presented in online APPENDIX IV.

Jeon and $\mathrm{Wu}(2014)$ document evidence of different reactions of bank lending to monetary policy in Asia during the global financial crisis of 2008-2009.7 We follow Jeon and Wu in using a dummy variable (Crisis) set to one for the 2008-2009 crisis period. Specifically, we control for $M P_{j t} \times C r i s i s$, Parents ${ }_{i j t}^{(1)} \times M P_{j t} \times$ Crisis and Parents $s_{i j t}^{(2)} \times M P_{j t} \times C r i s i s$. As we discuss in Section 5.1.3, this specification allows us to measure the impact of monetary policy on bank lending separately for the crisis and non-crisis periods across the different bank types ${ }^{8}$

\footnotetext{
${ }^{7}$ As discussed in Section 2, Jeon and Wu (2014) found that Foreign banks operating in Asia reduced bank lending (quantity) to a larger extent than domestically-owned banks during the 2008-2009 financial crisis period. They argue that this is indirect evidence that foreign-owned banks reallocated liquidity to their head offices in the face of financial stress. This in turn negated any expansionary effect on lending from an easing of monetary policy at that time.

${ }^{8}$ We treat $2008 / 09$ as the global financial crisis period, rather than the alternative of $2007 / 08$. This follows
} 
BankChar $_{i j t}$ consists of bank-level characteristics that measure idiosyncratic features, other than their ownership types, and are included to partial out the effects of the bank characteristics on the loan supply. This includes relevant indicators measuring the degree of Liquidity and Capitalization, Size, Riskiness and Profitability, as defined in Section 4.1. They are included in line with empirical evidence from relevant literature on bank lending channel. The literature suggests that banks that are more liquid, more capitalized and larger in size, are better able to access alternative options to finance their loans, and thus, would be less responsive to monetary policy shocks. The riskiness of bank customers and bank profitability are also amongst the controls as these factors may influence the supply of bank loans. We transform each bank characteristic variable into dummy variables equal to one if the variable is above the median value in the distribution of the variables of all observations of each country in each year, and zero otherwise 9 To avoid reverse causation, we include a one-year lag of these bank characteristic variables.

Macro $_{j t}$ includes a set of country-specific variables of country $j$ in year $t$ that are relevant to macroeconomic conditions. It includes the real GDP growth rate and the unemployment rate to control for demand-side effects on loan quantities and prices. BankSec $j_{j t}$ represents national banking sector characteristics and include Financial depth and the HHI. Financial depth denotes the overall size of the financial resources provided to the private sector; HHI stands for the degree of concentration or competition in the banking industry. bank $k_{i}$ indicates bank-fixed effects.

The motivation for the inclusion of bank characteristics and macroeconomic indicators also draws on our consideration of issues of endogeneity and selection bias in the context of testing the hypothesis that global banks lead to a hampering of monetary policy transmission. In our basic regression the monetary policy measure is unlikely to be directly endogenous to the dependent variable, namely bank level lending growth, because monetary policy is set in light of aggregate economic conditions rather than the behaviour of any single bank. Of course, it is possible that aggregate conditions in each country play a large part in shaping both individual bank lending and the setting of monetary policy, and this is the justification for the aggregate controls described above. In following this approach we draw on a long line of literature using

the earlier work of Jeon and $\mathrm{Wu}(2014)$. It is also important to note that whilst the crisis started to break in the United States in the second half of 2007, exceptional movements in lending statistics in Asian countries started in 2008, for instance in our sample local credit (credit to non-financial private sector) and cross-border interbank borrowing show expansion until 2007, and then started to collapse in 2008. Similarly, loan growth of the banks in our sample showed increases in 2007, before shrinking in 2008 and 2009.

${ }^{9}$ We transform each bank characteristic variable into a binary dummy variable since we do not expect the relationships between characteristics and the impact of monetary policy indicator to be so well defined that they hold continuously. In robustness tests we instead use original values of the bank characteristics and find that this does not affect the main results, see online APPENDIX VI. 
bank-level panel data to explore the heterogeneity in the effects of monetary policy on bank lending, including the paper of Jeon and Wu (2014). The maintained assumption here, and in related literature, is that the GDP growth rate and unemployment are the drivers of endogenous monetary policy actions that may correlate with bank lending movements (note that we do not control for inflation rates in this context given that bank level lending quantities and interest rates are specified in real terms).

A related, perhaps deeper, concern is that of possible selection bias. In particular, it could be that some group of banks naturally exhibit less sensitivity to monetary policy so that there appears to be hampering of policy transmission in the group (e.g. perhaps these banks have better access to stable and resilient external wholesale funding sources), and that these banks are also more likely to be successful, to expand and to buy up foreign subsidiaries, so becoming Parents. If this were true then evidence for a hampering of policy amongst Parents would be spurious, and reflect only a selection of banks with resilient funding sources. This is a concern in all work of this type and we follow the standard approach in the literature which is to hold constant observable bank characteristics such as size, liquidity and capitalization. The logic here is that these observable characteristics correlate with unobserved factors that may affect banks' ability to shield their balance sheets, e.g. the largest banks may cherry pick the most resilient wholesale funding supplier whose funding supply is least cyclically sensitive. Thus, by controlling for a range of bank characteristics, we hope to eliminate channels through which a hampering effect occurs spuriously. This is the main perspective on handling the effects of selection bias adopted in the literature and followed by, for instance, Jeon and Wu (2014).

A comparison of two parents A comparison of the Parents $^{(1)}$ and Parents ${ }^{(2)}$ banks provides another perspective on the selection bias concern, namely that the global banks that we have identified are simply the larger and more successful banks whose lending behaviour is inherently more stable in the face of monetary policy changes. In Table 4 we report both the average total asset value of each type of banks as well as the average assets held in their foreign subsidiaries, for the years 2000 and 2014. In both years the Parents ${ }^{(1)}$ average for total assets, measured by both the mean and the median, is lower than the Parents ${ }^{(2)}$ average. In others words, whilst the Parents ${ }^{(1)}$ banks access larger foreign subsidiary resources, they are on average smaller banks than those in the Parents ${ }^{(2)}$ group. This is the opposite of what one would expect if it is the case that groups form endogenously through successful domestic banks (possibly with resilient wholesale funding suppliers) expanding into foreign markets to become Parents. We interpret this observation as evidence against the critique that the results that we estimate will reflect selection bias. 
Table 4: Comparison of two Parents groups in size

\begin{tabular}{cccc}
\hline \hline \multirow{2}{*}{ Two Parents groups } & \multicolumn{2}{c}{ Parents $^{\prime}$ size (bill. US\$) } & \multirow{2}{*}{ Juniors size $^{2)}(\%)$} \\
\cline { 2 - 3 } & 2000 & 2014 & \\
\hline \multirow{2}{*}{ Parents $^{(1)}$} & 27.7 & 108.8 & 31.30 \\
& $(25.5)$ & $(78.1)$ & $(25.71)$ \\
Parents $^{(2)}$ & 34.1 & 114.8 & 0.70 \\
& $(25.9)$ & $(89.8)$ & $(0.68)$ \\
\hline
\end{tabular}

Notes: 1) Parents are divided into two subgroups based on the total asset size of all Juniors they have as a ratio to the Parents ${ }^{\prime}$ asset. Parents ${ }^{(1)}$ is the group of Parents that have relatively larger Juniors and Parents ${ }^{(2)}$ is the group of Parents that have relatively small Juniors. The threshold for this distinction is median value $(1.99 \%)$, as explained in Figure 3 in Section 3.2.

2) Size of total assets of all Juniors affiliated with Parents ${ }^{(1)}$ and Parents ${ }^{(2)}$, respectively (as a ratio to the Parents' ${ }^{\prime}$ asset), 3) mean value (median in parentheses)

\subsubsection{Estimation method}

Estimation is by Ordinary Least Squares. It may be the case that the error terms are not independent and identically distributed, but might be clustered (e.g. observations within each bank group are correlated, but banks from different groups are not correlated). We therefore cluster the standard errors at the bank-level, so that the standard errors are asymptotically robust to both heteroscedasticity and serial correlation. As noted above we use bank-fixed effects to control for bank-level heterogeneity not captured in other controls. In variations on our baseline specification we also examine results from the random effects estimator in Section 5.3 .

\subsubsection{Estimation results}

Loan quantity equation Table 5 shows the estimation results of Equation (1) with $\Delta l n L o a n_{i j t}$ as dependent variables. Coefficient estimates and corresponding p-values are reported. To save space, we present the coefficients on key variables relevant to $M P_{j t}$, Parents $s_{i j t}$, and Crisis. Column (1) is the baseline estimate. Column (2) is from a regression that excludes the controls for financial depth and banking sector concentration. Column (3) adds time dummies to the column (1) estimate, while column (4) omits bank level fixed effects that are included in baseline regression. 
Table 5: Loan quantity equation $(2000-2014)$

\begin{tabular}{|c|c|c|c|c|}
\hline & \multicolumn{4}{|c|}{ Dependent: $\Delta \ln L_{o a n}{ }_{i j t}$} \\
\hline & (1) & $(2)$ & (3) & (4) \\
\hline$M P$ & $\begin{array}{r}-1.128^{* * *} \\
(0.000)\end{array}$ & $\begin{array}{r}-1.277^{* * *} \\
(0.000)\end{array}$ & $\begin{array}{r}-1.290^{* * *} \\
(0.000)\end{array}$ & $\begin{array}{r}-1.180^{* * *} \\
(0.000)\end{array}$ \\
\hline$M P \times C r i s i s$ & $\begin{array}{r}2.464^{* * *} \\
(0.001)\end{array}$ & $\begin{array}{r}2.407^{* * *} \\
(0.002)\end{array}$ & $\begin{array}{l}1.897^{*} \\
(0.053)\end{array}$ & $\begin{array}{r}2.952^{* * *} \\
(0.000)\end{array}$ \\
\hline Parents $^{(1)} \times M P$ & $\begin{array}{r}1.725 \\
(0.104)\end{array}$ & $\begin{array}{r}1.647 \\
(0.121)\end{array}$ & $\begin{array}{r}1.590 \\
(0.139)\end{array}$ & $\begin{array}{c}1.758^{*} \\
(0.059)\end{array}$ \\
\hline Parents $^{(1)} \times M P \times$ Crisis & $\begin{array}{l}-3.128 \\
(0.132)\end{array}$ & $\begin{array}{r}-3.072 \\
(0.143)\end{array}$ & $\begin{array}{r}-2.956 \\
(0.133)\end{array}$ & $\begin{array}{r}-2.146 \\
(0.290)\end{array}$ \\
\hline Parents $^{(2)} \times M P$ & $\begin{array}{r}0.063 \\
(0.940)\end{array}$ & $\begin{array}{r}0.281 \\
(0.745)\end{array}$ & $\begin{array}{r}0.149 \\
(0.843)\end{array}$ & $\begin{array}{r}-0.095 \\
(0.917)\end{array}$ \\
\hline Parents $^{(2)} \times M P \times$ Crisis & $\begin{array}{r}1.368 \\
(0.289)\end{array}$ & $\begin{array}{r}1.241 \\
(0.353)\end{array}$ & $\begin{array}{r}0.938 \\
(0.435)\end{array}$ & $\begin{array}{r}1.443 \\
(0.285)\end{array}$ \\
\hline$R^{2}$ & 0.186 & 0.181 & 0.192 & 0.055 \\
\hline Observations & 2,613 & 2,613 & 2,613 & 2,613 \\
\hline \multicolumn{5}{|l|}{ wald test } \\
\hline \multicolumn{5}{|l|}{ Non-crisis period ${ }^{2)}$} \\
\hline Parents ${ }^{(1)}$ & $\begin{array}{r}0.597 \\
(0.561)\end{array}$ & $\begin{array}{r}0.369 \\
(0.719)\end{array}$ & $\begin{array}{r}0.300 \\
(0.775)\end{array}$ & $\begin{array}{r}0.578 \\
(0.521)\end{array}$ \\
\hline Parents ${ }^{(2)}$ & $\begin{array}{r}-1.065 \\
(0.173)\end{array}$ & $\begin{array}{r}-0.996 \\
(0.222)\end{array}$ & $\begin{array}{r}-1.141 \\
(0.125)\end{array}$ & $\begin{array}{l}-1.275 \\
(0.145)\end{array}$ \\
\hline \multicolumn{5}{|l|}{ Crisis period $^{3)}$} \\
\hline$M P+M P \times C r i s i s$ & $\begin{array}{l}1.337^{*} \\
(0.066)\end{array}$ & $\begin{array}{r}1.130 \\
(0.119)\end{array}$ & $\begin{array}{r}0.607 \\
(0.518)\end{array}$ & $\begin{array}{r}1.772^{* *} \\
(0.018)\end{array}$ \\
\hline Parents ${ }^{(1)}$ & $\begin{array}{l}-0.066 \\
(0.965)\end{array}$ & $\begin{array}{l}-0.296 \\
(0.847)\end{array}$ & $\begin{array}{r}-0.758 \\
(0.618)\end{array}$ & $\begin{array}{r}1.383 \\
(0.329)\end{array}$ \\
\hline Parents ${ }^{(2)}$ & $\begin{array}{r}2.768^{* * * *} \\
(0.000)\end{array}$ & $\begin{array}{r}2.652^{* * * *} \\
(0.000)\end{array}$ & $\begin{array}{l}1.695^{*} \\
(0.073)\end{array}$ & $\begin{array}{r}3.121^{* * *} \\
(0.000)\end{array}$ \\
\hline
\end{tabular}

Notes: 1) p-values are in parentheses. ***: significant at $1 \%$ level, **: significant at $5 \%$ level, *: significant at $10 \%$ level, Standard errors are corrected for heteroscedasticity and clustered at bank level to control for the effects of residual autocorrelation. 2) Column (1): baseline regression, Column (2): Financial depth and HHI are excluded, Column (3): time-fixed effects is included, Column (4): bank-fixed effects is excluded.

2) Parents $^{(1)}:$ sum of coefficients on $M P, M P \times$ Parents $^{(1)}$,

Parents $^{(2)}$ : sum of coefficients on $M P, M P \times$ Parents $^{(2)}$

3) Parents $^{(1)}:$ sum of coefficients on $M P, M P \times C$ risis, Parents ${ }^{(1)} \times M P$, and Parents $^{(1)} \times M P \times$ Crisis,

Parents $^{(2)}:$ sum of coefficients on $M P, M P \times$ Crisis, $_{\text {Parents }}^{(2)} \times M P$, and Parents $^{(2)} \times M P \times$ Crisis

4) Number of Parents ${ }^{(1)}$ and Parents ${ }^{(2)}$ are 18 and 16, respectively (The sum of these exceeds total number of Parents (26), reflecting that some Parents experienced changes in their groups during the period).

First, we find that Parents ${ }^{(1)}$ hamper the effects of monetary policy. The coefficients on $M P_{j t}$ are consistently negative and significant, implying that a bank lending channel exists amongst domestic banks. From the baseline model, Regression (1), it can be observed that 
domestic banks reduce real loan growth rates by about 1.128 percentage points in response to a 1 percentage point increase in money market rates. In contrast, the coefficient on Parents ${ }_{i j t}^{(1)} \times M P$ is 1.725; it is larger than the coefficient on $M P_{j t}$ in absolute value. The sum of the coefficients on $M P_{j t}$ and Parents $(1) \times M P_{j t}$ is 0.597 , implying that larger Parents do not reduce the growth of their loan quantity, i.e. the bank lending channel is stifled, possibly as a result of global banks being able to shield lending through tapping the resources of foreign subsidiaries. In contrast, we do not find significant hampering effect of Parents ${ }^{(2)}$. The result is in line with our expectation that the hampering effects of monetary policy amongst Parents are stronger when there is access to greater foreign subsidiary resources. A caveat that should be recognised is that this evidence, whilst consistent across the estimates in panel of Table 5, is only borderline significant. Specifically, the hampering effect is significant at the $10 \%$ level in column (4), and at the $15 \%$ level in columns (1), (2) and (3).

The interaction term featuring monetary policy and the crisis dummy is consistently positive and significant. Furthermore, it is larger in magnitude than the negative coefficient on monetary policy that applies for other parts of the sample. This implies that during the two years of the crisis a tightening of lending occurred amongst domestic banks despite the easing of monetary policy that took place at that time, i.e. for domestic banks the effect of monetary policy on bank lending was of unexpected sign for the years 2008 and 2009. However, during this period a tightening of bank lending was not observed amongst the global banks with access to greatest foreign subsidiary resources - in the section headed Wald tests the effect of monetary policy on bank lending amongst the group Parents ${ }^{(1)}$ is slightly negative in three out of four cases and is always insignificantly different from zero. One interpretation of these findings is that deteriorating financial conditions forced a lending reversal for domestic banks despite monetary policy being eased, but this effect was less pronounced amongst global banks who could draw on subsidiary resources to stabilize their lending in the face of deteriorating financial conditions. This logic fits very neatly with the conclusions of by Jeon and Wu (2014). Those authors found that foreign-owned banks in the Asia region cut their lending in response to monetary easing during the crisis and interpreted the finding as evidence that foreign-owned banks (in our study the Juniors of Parents) were diverting resources to foreign owners. The global banks that we find not to have cut their lending during 2008 and 2009 are the beneficiaries of the resource transfers that undermined the foreign banks studied by Jeon and Wu (2014).

Loan price equation Table 6 shows the estimation results of Equation (1) with $\Delta$ lnLoan rate ijt as the dependent variable.

We find domestic banks adjust loan interest rates in line with a change in domestic monetary 
tightening, supporting the existence of the bank lending channel. In the baseline model, Regression (1), the coefficient on $M P_{j t}$ is 0.426 and highly significant. This means that the reference group increases the real loan interest rate by 0.426 percentage points when the monetary policy rate rises by 1 percentage point (interest rate pass-through is less than one but recall that the dependent variable is a real interest rate whilst the explanatory variable is a nominal interest rate).

The difference in the the hampering effects between Parents ${ }^{(1)}$ and Parents ${ }^{(2)}$ becomes more pronounced. In the baseline regression the coefficient on Parents $s_{i j t}^{(1)} \times M P_{j t}$ is -0.174 and significant at the $5 \%$ level. This shows that Parents with larger Juniors adjust loan interest rates by roughly two thirds the amount of domestic banks following a tightening of monetary policy. This is in line with our main hypothesis that the transmission of central bank policy is hampered by the existence of globally diversified banks who may shield themselves from more expensive funding conditions through drawing on the resources of their foreign subsidiaries. In contrast, the coefficient for the interaction between monetary policy and Parents ${ }^{(2)}$ is positive and significant in all columns in Panel B, indicating that, rather than a hampering of policy transmission, there is amplification of policy transmission to commercial lending rates for global banks with relatively small foreign subsidiaries. This is a puzzling feature in our results, though it should be noted that the effect is quantitatively smaller than the hampering effect observed for the Parents ${ }^{(1)}$ group, so that the total effect from the presence of global banks is to hamper the transmission of monetary policy.

During the crisis period of 2008 and 2009 monetary policy interest rates were being reduced. For domestic banks the transmission to commercial interest rates was 0.059, for the group Parents $^{(1)}$ it was 0.169 , and for the group Parents ${ }^{(2)}$ it was 0.179 . Thus, whilst the transmission of looser monetary policy during the crisis years was less than during the rest of the sample, this was more true for domestic banks than it was for global banks. As argued in the discussion of the lending quantity results, this could be because the global banks were better able to resist pressures to tighten lending terms that were brought about by the crisis. 
Table 6: Loan price equation $(2000-2014)$

\begin{tabular}{|c|c|c|c|c|}
\hline & \multicolumn{4}{|c|}{ Dependent: $\Delta$ Loan rate ijt } \\
\hline & (1) & $(2)$ & (3) & (4) \\
\hline$M P$ & $\begin{array}{r}0.426^{* * *} \\
(0.000)\end{array}$ & $\begin{array}{r}0.428^{* * * *} \\
(0.000)\end{array}$ & $\begin{array}{r}0.387^{* * *} \\
(0.000)\end{array}$ & $\begin{array}{r}0.412^{* * *} \\
(0.000)\end{array}$ \\
\hline$M P \times C r i s i s$ & $\begin{array}{r}-0.367^{* * *} \\
(0.000)\end{array}$ & $\begin{array}{r}-0.364^{* * *} \\
(0.000)\end{array}$ & $\begin{array}{r}-0.323^{* * *} \\
(0.001)\end{array}$ & $\begin{array}{r}-0.345^{* * *} \\
(0.000)\end{array}$ \\
\hline Parents $^{(1)} \times M P$ & $\begin{array}{r}-0.174^{* *} \\
(0.024)\end{array}$ & $\begin{array}{r}-0.172^{* *} \\
(0.023)\end{array}$ & $\begin{array}{r}-0.203^{* * *} \\
(0.002)\end{array}$ & $\begin{array}{r}-0.149^{* *} \\
(0.045)\end{array}$ \\
\hline Parents $^{(1)} \times M P \times C$ risis & $\begin{array}{r}0.284^{* * *} \\
(0.004)\end{array}$ & $\begin{array}{r}0.275^{* * *} \\
(0.005)\end{array}$ & $\begin{array}{r}0.323^{* * *} \\
(0.002)\end{array}$ & $\begin{array}{r}0.257^{* * *} \\
(0.005)\end{array}$ \\
\hline Parents $^{(2)} \times M P$ & $\begin{array}{r}0.125^{* * *} \\
(0.002)\end{array}$ & $\begin{array}{r}0.122^{* * *} \\
(0.002)\end{array}$ & $\begin{array}{r}0.088^{* *} \\
(0.017)\end{array}$ & $\begin{array}{r}0.132^{* * *} \\
(0.001)\end{array}$ \\
\hline Parents $^{(2)} \times M P \times$ Crisis & $\begin{array}{l}-0.005 \\
(0.969)\end{array}$ & $\begin{array}{r}-0.008 \\
(0.949)\end{array}$ & $\begin{array}{r}0.044 \\
(0.785)\end{array}$ & $\begin{array}{r}-0.008 \\
(0.941)\end{array}$ \\
\hline$R^{2}$ & 0.255 & 0.255 & 0.280 & 0.215 \\
\hline Observations & 2,613 & 2,613 & 2,613 & 2,613 \\
\hline \multicolumn{5}{|l|}{ wald test } \\
\hline \multicolumn{5}{|l|}{ Non-crisis period ${ }^{2)}$} \\
\hline Parents $^{(1)}$ & $\begin{array}{r}0.252^{* * * *} \\
(0.001)\end{array}$ & $\begin{array}{r}0.256^{* * *} \\
(0.000)\end{array}$ & $\begin{array}{r}0.183^{* * *} \\
(0.003)\end{array}$ & $\begin{array}{r}0.263^{* * *} \\
(0.000)\end{array}$ \\
\hline Parents $^{(2)}$ & $\begin{array}{r}0.551^{* * *} \\
(0.000)\end{array}$ & $\begin{array}{r}0.551^{* * *} \\
(0.000)\end{array}$ & $\begin{array}{r}0.474^{* * *} \\
(0.000)\end{array}$ & $\begin{array}{r}0.544^{* * *} \\
(0.000)\end{array}$ \\
\hline \multicolumn{5}{|l|}{ Crisis period $^{3)}$} \\
\hline$M P+M P \times C r i s i s$ & $\begin{array}{r}0.059 \\
(0.402)\end{array}$ & $\begin{array}{r}0.064 \\
(0.359)\end{array}$ & $\begin{array}{r}0.064 \\
(0.471)\end{array}$ & $\begin{array}{r}0.067 \\
(0.295)\end{array}$ \\
\hline Parents $^{(1)}$ & $\begin{array}{r}0.169^{* *} \\
(0.044)\end{array}$ & $\begin{array}{r}0.166^{* *} \\
(0.046)\end{array}$ & $\begin{array}{c}0.183^{*} \\
(0.059)\end{array}$ & $\begin{array}{r}0.175^{* *} \\
(0.024)\end{array}$ \\
\hline Parents $^{(2)}$ & $\begin{array}{r}0.179 \\
(0.140)\end{array}$ & $\begin{array}{r}0.179 \\
(0.138)\end{array}$ & $\begin{array}{r}0.195 \\
(0.180)\end{array}$ & $\begin{array}{c}0.191^{*} \\
(0.079)\end{array}$ \\
\hline
\end{tabular}

Notes: 1) p-values are in parentheses. ***: significant at $1 \%$ level, **: significant at $5 \%$ level, *: significant at $10 \%$ level, Standard errors are corrected for heteroscedasticity and clustered at bank level to control for the effects of residual autocorrelation. 2) Column (1): baseline regression, Column (2): Financial depth and HHI are excluded, Column (3): time-fixed effects is included, Column (4): bank-fixed effects is excluded.

2) Parents $^{(1)}$ : sum of coefficients on $M P, M P \times$ Parents $^{(1)}$,

Parents $^{(2)}$ : sum of coefficients on $M P, M P \times$ Parents $^{(2)}$

3) Parents $^{(1)}:$ sum of coefficients on $M P, M P \times$ Crisis, $_{\text {Parents }}^{(1)} \times M P$, and Parents $^{(1)} \times M P \times$ Crisis,

Parents $^{(2)}:$ sum of coefficients on $M P, M P \times$ Crisis, $_{\text {Parents }}^{(2)} \times M P$, and Parents $^{(2)} \times M P \times$ Crisis

4) Number of Parents ${ }^{(1)}$ and Parents ${ }^{(2)}$ are 18 and 16, respectively (The sum of these exceeds total number of Parents (26), reflecting that some Parents experienced changes in their groups during the period). 


\subsection{Internal capital markets in global banks}

To find more concrete evidence for the operational internal capital market between Parents and Juniors, we examine whether the bank lending of Juniors is affected by the financial conditions of their Parents. We conjecture that in freely working internal capital markets the loan growth of Juniors will be less dependent on their own internal funds when Parents are in good financial condition. The framework that we use to explore this issue is based on Jeon et al. (2013).

Data description For this section, we construct a new bank-level annual panel dataset that includes 26 Parents and the 82 Juniors affiliated with them, for 548 bank-year observations, from 2000 to 2014: 10 The Juniors operate in 19 countries, either in the Asia region or in other countries. Note that 30 out of the 82 Juniors operate in one of the eight Asian countries; these were classified as Foreign banks in our previous regressions.

In addition to the bank-level variables described in the first dataset, we include an additional bank-level indicator, Internal funds $(I F)$, that is defined as the ratio of net income to loans outstanding. It measures the size of the internally generated funds available (net income) relative to total lending. All other bank characteristics are constructed in the same manner as in the previous sections (explained in Section 4.1 and online APPENDIX I). In this specification, however, we do not transform bank characteristics variable into dummy variables as we did in previous sections.

The country-level macroeconomic indicators include the overnight money market rate, the real GDP growth rate and unemployment rate for both the 8 home countries where Parents operate and the 19 host countries where the Juniors are located. For the countries where the money market rates are unavailable, we use instead either the central bank policy rate or the discount rate. All of the macroeconomic data were collected from the International Financial Statistics (IFS) of the International Monetary Fund (IMF).

Estimation model Using the specification model of Equation (2), we measure how Junior s' dependence on its own internal funds for lending are affected by the Parents' financial conditions 11

\footnotetext{
${ }^{10}$ The total number of Juniors effectively used is restricted to 62 because of a lack of data availability. This might reflect that many Juniors are very small banks in the host countries.

${ }^{11}$ The model basically follows Jeon et al. (2013). The main difference is that the model used here does not include 1-year lag of dependent variable and is estimated by OLS with fixed effects in line with the models in previous sections.
} 


$$
\begin{aligned}
\Delta \operatorname{lnLan}_{j k p t}^{J} & =\beta_{0}+\beta_{1} M P_{k t}+\beta_{2} I F_{j k p t}^{J}+\beta_{3}\left(I F_{j k p t}^{J} \times F C_{p t-1}^{P}\right)+\beta_{4} F C_{p t-1}^{P} \\
& +\beta_{5} \text { BankChar }{ }_{j k p t-1}^{J}+\beta_{6} \text { Control }+ \text { bank }_{j}+\epsilon_{j k p t}
\end{aligned}
$$

where,

- $\Delta \operatorname{lnLoan^{J}} \quad$ : real loan growth rate of Juniors

- IF $\quad$ : Juniors' ${ }^{J}$ internal funds (Net Income)

- $F C^{P} \quad$ : Parents' ${ }^{\prime}$ financial condition, [Internal funds(IF), Liquidity, Capitalization]

- BankChar ${ }^{J} \quad$ : bank characteristics Juniors in $t-1$

- Control : $\left[G D P_{k t}, U_{n e m_{k t}}, G D P_{m t-1}, U_{\left.n e m_{m t-1}, M P_{m t-1}\right]}\right.$

In Equation (2), $j$ denotes Juniors and $p$ denotes the Parents with which the Junior $j$ is affiliated. $k$ stands for the host country where Junior $j$ operates; $t$ denotes time. The dependent variable $\Delta \operatorname{lnLoan}_{j k p t}^{J}$ represents the real loan growth rate of Junior $j$ operating in host country $k$, affiliated with the parent bank $j$ in the home country $m$ in year $t . I F_{j k p t}^{J}$ denotes Junior $j$ 's internal funds in year $t$, while $F C_{p t-1}^{P}$ denotes the Parent $p$ 's financial conditions in year $t-1$.

As a measure of the financial conditions of the Parents, we consider three variables: Internal funds (Net income), Liquidity and Capitalization. Both Liquidity and Capitalization are defined as the ratio to total assets. BankChar ${ }_{j k p t}^{J}$ includes bank-level characteristics of Juniors, including Liquidity, Capitalization, Size, Riskiness and Profitability, as defined in Section 4.1. Control includes macroeconomic conditions (real GDP growth rate and unemployment rate) of both home in $t$ and host countries in $t-1$, and the monetary policy indicator of host countries in $t-1$. In the case of host countries, we adopt a one-year lag of macroeconomic variables in line with a one-year lag of Parents' bank-level indicators. bank $k_{j}$ is bank-level fixed effects.

We expect that the coefficients on $I F_{j k p t}^{J}$ and $F C_{p t-1}^{P}$ are positive, implying that ample internal capital, either of their own or of their Parents', helps increase the real loan growth of Juniors. The coefficient of the interaction term $I F_{j k p t}^{J} \times F C_{p t-1}^{P}$ would capture how the marginal dependence of the Juniors on its internal funds are affected by Parents ${ }^{\prime}$ financial conditions. A negative coefficient would imply that a strong financial condition of the Parents helps Juniors depend less on internal funds. We will interpret such an outcome as evidence for the operation of internal capital markets.

In a symmetric way, we regress Parents ${ }^{\prime}$ real loan growth on their internal funds and the interaction term with their Juniors ${ }^{\prime}$ financial conditions, as in Equation (3). In this equation, $m$ stands for the the home country in which Parents $p$ operate. The rationale is the same 
as in Equation (2), aiming to examine whether Juniors financial conditions affect Parents' dependence on their own internal funds.

Equations (2) and (3) are estimated by OLS with clustered standard errors. The sample period covers 2000-14.

$$
\begin{aligned}
\Delta \operatorname{lnLoan}_{p t}^{P} & =\beta_{0}+\beta_{1} M P_{m t}+\beta_{2} I F_{p t}^{P}+\beta_{3}\left(I F_{p t}^{P} \times F C_{j k p t-1}^{J}\right)+\beta_{4} F C_{j k p t-1}^{J} \\
& +\beta_{5} \text { BankChar }_{p t-1}^{P}+\beta_{6} \text { Control }+ \text { bank }_{p}+\epsilon_{p t}
\end{aligned}
$$

Estimation results Our results are shown in Panels A and B of Table 7. In Panel A (dependent variable: Juniors' real loan growth rate) the monetary policy indicator is negative whilst the coefficient on internal funds of the Junior is positive, as expected, though only the latter is statistically significant. In column (1), of the three interactions between internal funds and the characteristics of parent banks, two (liquidity and capitalization) are negatively signed but only capitalization is significant at the $10 \%$ level. One reason for the imprecise results could be multicollinearity arising from correlations between Parent characteristics. When the three interaction terms are included separately in columns (2) to (4) all are negatively signed, liquidity is significant at the $5 \%$ level and capitalization is significant at the $1 \%$ level. These results therefore provide some evidence that when parent bank liquidity and capitalization deteriorate the dependence of Juniors affiliated with the Parents on internal funds to generate loans (essentially the severity of the funding constraint on Juniors) increases. One reason for this finding could be that in these circumstances Parents react to tighter financial conditions in their main markets by drawing on the funds of their foreign subsidiaries. This is precisely the behaviour that underpins the hampering of monetary policy reported in our main results: Tighter monetary policy in the main market for a parent bank will trigger declines in the liquidity and capitalization ratios for such banks and these in turn will trigger an offsetting flow of resources from Juniors to Parents giving a hampering of policy transmission in the country in which the Parents operate.

In Panel B (dependent: Parents' real loan growth rate), we find that all coefficients on the three interaction terms are negative, in line with our expectation. However, none of these effects are statistically significant, either in the general regression in column (1) or the regressions that control for one interaction at a time (columns (2) to (4)). Thus, there is only weak support for the idea that the balance sheet conditions of Juniors makes a difference to the way in 
which their Parents finance their lending operations in their main markets. The reason for this may be that Juniors are small in size relative to their Parents, so that whilst in Panel A we find evidence that the characteristics of Parents matter for how Juniors choose to fund their lending, the reverse evidence is harder to pin down in the data, leading to the statistically insignificant estimates in Panel B. 
Table 7: Interdependence on financial conditions $(2000-2014)$

\begin{tabular}{|c|c|c|c|c|c|c|c|c|c|}
\hline & \multicolumn{4}{|c|}{$\begin{array}{l}\text { Panel A. Juniors' real loan growth } \\
\text { Dependent: } \Delta \text { lnLoan } \text { likpt }^{J}\end{array}$} & & \multicolumn{4}{|c|}{$\begin{array}{l}\text { Panel B. Parents' real loan growth } \\
\text { Dependent: } \Delta \ln \operatorname{Loan}_{p t}^{P}\end{array}$} \\
\hline & (1) & (2) & (3) & (4) & & (1) & (2) & (3) & (4) \\
\hline$M P_{k}$ & $\begin{array}{r}-0.698 \\
(0.239)\end{array}$ & $\begin{array}{l}-0.503 \\
(0.364)\end{array}$ & $\begin{array}{r}-0.540 \\
(0.367)\end{array}$ & $\begin{array}{r}-0.673 \\
(0.278)\end{array}$ & $M P_{m}$ & $\begin{array}{r}0.021 \\
(0.963)\end{array}$ & $\begin{array}{r}0.043 \\
(0.925)\end{array}$ & $\begin{array}{r}0.015 \\
(0.973)\end{array}$ & $\begin{array}{r}-0.002 \\
(0.996)\end{array}$ \\
\hline$I F^{J}$ & $\begin{array}{r}6.715^{* * *} \\
(0.000)\end{array}$ & $\begin{array}{r}1.771^{* *} \\
(0.019)\end{array}$ & $\begin{array}{r}3.650^{* *} \\
(0.011)\end{array}$ & $\begin{array}{r}5.894^{* * *} \\
(0.000)\end{array}$ & $I F^{P}$ & $\begin{array}{r}4.773^{* * *} \\
(0.000)\end{array}$ & $\begin{array}{r}3.699 * * * \\
(0.000)\end{array}$ & $\begin{array}{r}3.745^{* * *} \\
(0.002)\end{array}$ & $\begin{array}{r}4.448^{* * *} \\
(0.001)\end{array}$ \\
\hline$I F^{J} \times I F^{P}$ & $\begin{array}{r}0.198 \\
(0.672)\end{array}$ & $\begin{array}{r}-0.279 \\
(0.512)\end{array}$ & & & $I F^{P} \times I F^{J}$ & $\begin{array}{r}-0.058 \\
(0.378)\end{array}$ & $\begin{array}{r}-0.069 \\
(0.359)\end{array}$ & & \\
\hline$I F^{J} \times$ Liquidity $^{P}$ & $\begin{array}{l}-0.060 \\
(0.435)\end{array}$ & & $\begin{array}{r}-0.120^{* *} \\
(0.048)\end{array}$ & & $I F^{P} \times$ Liquidity $^{J}$ & $\begin{array}{l}-0.006 \\
(0.887)\end{array}$ & & $\begin{array}{r}-0.010 \\
(0.805)\end{array}$ & \\
\hline IF $^{J} \times$ Capitalization $^{P}$ & $\begin{array}{c}-0.512^{*} \\
(0.077)\end{array}$ & & & $\begin{array}{r}-0.511^{* * *} \\
(0.004)\end{array}$ & $I F^{P} \times$ Capitalization $^{J}$ & $\begin{array}{r}-0.050 \\
(0.403)\end{array}$ & & & $\begin{array}{r}-0.054 \\
(0.346)\end{array}$ \\
\hline$R^{2}$ & 0.214 & 0.176 & 0.189 & 0.212 & $R^{2}$ & 0.171 & 0.172 & 0.171 & 0.174 \\
\hline Observations & 539 & 539 & 539 & 539 & Observations & 548 & 548 & 548 & 548 \\
\hline Groups & 59 & 59 & 59 & 59 & Groups & 59 & 59 & 59 & 59 \\
\hline
\end{tabular}

Notes: 1) p-values are in parentheses. $* * *$ : significant at $1 \%$ level, $* *$ : significant at $5 \%$ level, *: significant at $10 \%$ level, Standard errors are corrected for heteroscedasticity and clustered at bank level to control for the effects of residual autocorrelation.

2) Column (1) includes all three variables indicative of financial conditions of either Parents (Panel A) or Juniors (Panel B) simultaneously, while Columns (2), (3), (4) consider one of these indicators separately. 3) The regression results are robust to some variations of baseline regression. The results remain essentially the same when we include time-fixed effects, or we exclude bank-level fixed effects, or we estimate the baseline model with random effects estimator. 


\subsection{Robustness tests}

We now examine the robustness of our main results. Table 8 presents robustness tests for the loan quantity results from Table 5, whilst Table 9 presents robustness tests for the loan price results from Table 6 . In both tables column (1) reproduces the baseline estimation results we have reported previously as column (1) in Table 5 and Table 6. In Regression (2), we include the bank characteristics as interactions with monetary policy in addition to including them as stand alone controls, i.e. we include BankChar ${ }_{i j t-1} \times M P_{j t}$ as well as BankChar ${ }_{i j t-1}$. This exercise is important given that in Section 5.1 we argued that controls such as bank size are one way in which we control for selection biases that may affect the relationship between the group of parent banks and the sensitivity of lending to monetary policy. In Regression (3), we use the random effects estimator instead of the fixed effects estimator. In Regression (4), we include all of the observations, without removing any of the outliers. In Regression (5) we control for the dummy variable (Foreign) that distinguishes foreign-owned banks from other types of banks and its interactions with monetary policy and the crisis episode indicator 12

In general our core results are robust to each of these extensions. Particularly important results are those in column (5) from each table, since these allow for a comparison of the impacts of global banks and foreign-owned banks on monetary transmission. A first observation is that during the non-crisis years, the basic hampering effects on monetary policy from the global banks with access to the greatest resources continue to be observed, even after controlling for the influence of foreign-owned banks on monetary transmission.

There are some further observations that we make given the earlier literature on the effects of bank ownership structures on monetary policy transmission in Asia during the global financial crisis. One is that we find, in line with Jeon and Wu (2014), that during the crisis years the total effect of monetary policy on bank lending quantities and prices is of unexpected sign amongst foreign-owned banks. This implies that when monetary policy was being relaxed during the crisis years, commercial lending quantities of foreign-owned banks went down, not up, and commercial lending rates of foreign banks went up rather than down. As discussed previously, Jeon and $\mathrm{Wu}$ attribute this behaviour to foreign-owned banks being forced to divert resources to their foreign-owners during the crisis, which constrained their lending despite the easing of monetary policy. In effect, there is a second form of hampering at work, in that central bank efforts to impart monetary stimulus in 2008-09 were hampered by the loss of funding for, and resultant tightening of lending conditions to, foreign-owned Asian banks. The hampering of monetary

\footnotetext{
${ }^{12}$ When we include this Foreign dummy, the reference banking group changes: In the previous section, the reference groups were Domestic banks and Foreign banks, and now it is Domestic banks only.
} 
stimulus during the crisis is less evident amongst global banks than it is amongst foreign-owned banks. One possible explanation is that that foreign-owned banks are more closely affiliated with banks in North America and Europe, where the crisis originated, and therefore experienced more dramatic changes in funding conditions.

In our final robustness exercise we address the fact that monetary policy transmission is often delayed beyond one year. We add to equation (1), and its equivalent for loan interest rates, the first lag of the monetary policy measure, plus its interaction with each of the variables with which the contemporaneous observation for monetary policy is interacted ${ }^{13}$ Using this dynamic model we report, in part VII of the online appendix, the effects of a monetary policy tightening on loan quantities and loan interest rates in the first year and in the first two years, for domestic banks, the Parents ${ }^{(1)}$ group and the Parents ${ }^{(2)}$ group. Results are reported for the four regression specifications used in Tables 5 and 6 (see the notes to APPENDIX VII for further details). For lending growth the total response to a monetary policy tightening after two years shows a similar pattern to that reported in our baseline results from Table 5 . In particular, across all specifications, there is a statistically significant decline in lending growth amongst domestic banks (see the first line of results) but amongst the Parents ${ }^{(1)}$ group of banks this effect is positive and statistically insignificant. Amongst the Parents ${ }^{(2)}$ group the effect remains negative but is statistically insignificant. Overall, there is a hampering of policy transmission amongst the global banks with access to greatest subsidiary resources, matching the insights from the static regression estimates. Turning to the results for loan interest rates, a slightly different picture emerges. In the year of a monetary policy tightening the loan interest rates charged by banks in the Parents ${ }^{(1)}$ group increase by approximately half the amount of domestic banks (compare the first and second rows in the second table in APPENDIX VII). One year later, however, the gap closes and there is essentially no difference between the degree of interest rate pass-through to domestic and global banks. This indicates that the hampering of monetary policy transmission to commercial interest rates is a temporary phenomenon - the largest global banks can resist passing on higher monetary policy interest rates for approximately one year, but at longer horizons their lending policies must reflect the central bank action.

\footnotetext{
${ }^{13}$ An alternative approach to capturing the dynamic effects of monetary policy would be to add lags of the dependent variable. However, due to the relatively short time dimension of our panel and the presence of bank fixed effects this would induce Nickell bias in the coefficient estimates, see Nickell (1981). Likewise, it is due to the relatively short time dimension of the panel that we do not include further lags of the monetary policy measure.
} 
Table 8: Robustness test (Corresponding Table 5)

\begin{tabular}{|c|c|c|c|c|c|}
\hline & \multicolumn{5}{|c|}{ Dependent: $\Delta \operatorname{lnLoan_{ijt}}$} \\
\hline & (1) & (2) & (3) & (4) & (5) \\
\hline$M P$ & $\begin{array}{r}-1.128^{* * *} \\
(0.000)\end{array}$ & $\begin{array}{r}-1.379^{*} \\
(0.066)\end{array}$ & $\begin{array}{r}-1.155^{* * *} \\
(0.000)\end{array}$ & $\begin{array}{r}-1.805^{* * *} \\
(0.000)\end{array}$ & $\begin{array}{r}-1.040^{* * *} \\
(0.004)\end{array}$ \\
\hline$M P \times C r i s i s$ & $\begin{array}{r}2.464^{* * *} \\
(0.001)\end{array}$ & $\begin{array}{r}0.919 \\
(0.580)\end{array}$ & $\begin{array}{r}2.524^{* * *} \\
(0.001)\end{array}$ & $\begin{array}{r}4.045^{* * *} \\
(0.000)\end{array}$ & $\begin{array}{r}1.289 \\
(0.111)\end{array}$ \\
\hline Parents $^{(1)} \times M P$ & $\begin{array}{r}1.725 \\
(0.104)\end{array}$ & $\begin{array}{l}2.029^{*} \\
(0.058)\end{array}$ & $\begin{array}{r}1.685^{*} \\
(0.097)\end{array}$ & $\begin{array}{r}2.038 \\
(0.183)\end{array}$ & $\begin{array}{r}1.629 \\
(0.134)\end{array}$ \\
\hline Parents $^{(1)} \times M P \times$ Crisis & $\begin{array}{l}-3.128 \\
(0.132)\end{array}$ & $\begin{array}{l}-2.316 \\
(0.294)\end{array}$ & $\begin{array}{l}-3.004 \\
(0.137)\end{array}$ & $\begin{array}{r}-4.284^{*} \\
(0.097)\end{array}$ & $\begin{array}{l}-1.961 \\
(0.349)\end{array}$ \\
\hline Parents $^{(2)} \times M P$ & $\begin{array}{r}0.063 \\
(0.940)\end{array}$ & $\begin{array}{r}0.084 \\
(0.925)\end{array}$ & $\begin{array}{r}0.080 \\
(0.923)\end{array}$ & $\begin{array}{r}0.704 \\
(0.449)\end{array}$ & $\begin{array}{r}-0.033 \\
(0.969)\end{array}$ \\
\hline Parents $^{(2)} \times M P \times$ Crisis & $\begin{array}{r}1.368 \\
(0.289)\end{array}$ & $\begin{array}{r}1.906 \\
(0.209)\end{array}$ & $\begin{array}{r}1.354 \\
(0.281)\end{array}$ & $\begin{array}{l}-0.268 \\
(0.855)\end{array}$ & $\begin{array}{l}2.533^{*} \\
(0.057)\end{array}$ \\
\hline Foreign $\times M P$ & & & & & $\begin{array}{r}-0.157 \\
(0.780)\end{array}$ \\
\hline Foreign $\times M P \times$ Crisis & & & & & $\begin{array}{l}2.793^{*} \\
(0.064)\end{array}$ \\
\hline$R^{2}$ & 0.186 & 0.187 & & 0.095 & 0.186 \\
\hline Observations & 2,613 & 2,613 & 2,613 & 2,927 & 2,613 \\
\hline
\end{tabular}

Notes: 1) p-values are in parentheses. ${ }^{* * *}$ : significant at $1 \%$ level, ${ }^{* *}$ : significant at $5 \%$ level, *: significant at $10 \%$ level, Standard errors are corrected for heteroscedasticity and clustered at bank level to control for the effects of residual autocorrelation.

2) Column (1): baseline results in Table 5, Column (2): Include interaction terms between MP and bank characteristics, Column (3): Random effects estimator is adopted, Column (4): Include all observations (no outlier removal procedure), Column (5): Include Foreign and its interaction terms with MP and Crisis.

\section{Conclusion}

In this paper we presented new evidence concerning the impact of banking sector globalization on monetary policy transmission in Asian countries. Our main findings parallel those of Cetorelli and Goldberg (2012a), who show that US banks with foreign subsidiaries are less responsive to monetary policy changes, possibly as a result of drawing on affiliate resources to offset increases in funding costs after a monetary policy contraction. Consistent with this interpretation, we show that Asian global banks with foreign subsidiaries that are larger by total asset value are better able to shield their lending in the aftermath of a tightening of monetary policy. We also showed that this behaviour is not observed during the financial crisis period of 2008-09, and that lending growth within networks of Asian banks is correlated with the financial status of other members of the network in a way consistent with the workings of internal capital 
Table 9: Robustness test (Corresponding Table 6)

\begin{tabular}{|c|c|c|c|c|c|}
\hline & \multicolumn{5}{|c|}{ Dependent: $\Delta$ Loan rate rijt } \\
\hline & (1) & $(2)$ & $(3)$ & (4) & $(5)$ \\
\hline$M P$ & $\begin{array}{r}0.426^{* * *} \\
(0.000)\end{array}$ & $\begin{array}{r}0.442^{* * *} \\
(0.000)\end{array}$ & $\begin{array}{r}0.418^{* * *} \\
(0.000)\end{array}$ & $\begin{array}{r}0.436^{* * *} \\
(0.000)\end{array}$ & $\begin{array}{r}0.447^{* * *} \\
(0.000)\end{array}$ \\
\hline$M P \times C$ risis & $\begin{array}{r}-0.367^{* * *} \\
(0.000)\end{array}$ & $\begin{array}{c}-0.211^{*} \\
(0.093)\end{array}$ & $\begin{array}{r}-0.353^{* * *} \\
(0.000)\end{array}$ & $\begin{array}{r}-0.348^{* * *} \\
(0.000)\end{array}$ & $\begin{array}{r}-0.238^{* * *} \\
(0.005)\end{array}$ \\
\hline Parents $^{(1)} \times M P$ & $\begin{array}{r}-0.174^{* *} \\
(0.024)\end{array}$ & $\begin{array}{c}-0.082 \\
(0.312)\end{array}$ & $\begin{array}{r}-0.161^{* *} \\
(0.025)\end{array}$ & $\begin{array}{r}-0.186^{* *} \\
(0.036)\end{array}$ & $\begin{array}{r}-0.193^{* *} \\
(0.014)\end{array}$ \\
\hline Parents $^{(1)} \times M P \times$ Crisis & $\begin{array}{r}0.284^{* * *} \\
(0.004)\end{array}$ & $\begin{array}{r}0.296^{* *} \\
(0.035)\end{array}$ & $\begin{array}{r}0.259^{* * *} \\
(0.005)\end{array}$ & $\begin{array}{r}0.267^{* *} \\
(0.011)\end{array}$ & $\begin{array}{r}0.154 \\
(0.141)\end{array}$ \\
\hline Parents $^{(2)} \times M P$ & $\begin{array}{r}0.125^{* * *} \\
\quad(0.002)\end{array}$ & $\begin{array}{r}0.200^{* * *} \\
(0.000)\end{array}$ & $\begin{array}{r}0.134^{* * *} \\
(0.001)\end{array}$ & $\begin{array}{r}0.112^{* * *} \\
(0.008)\end{array}$ & $\begin{array}{r}0.105^{* *} \\
(0.014)\end{array}$ \\
\hline Parents $^{(2)} \times M P \times$ Crisis & $\begin{array}{c}-0.005 \\
(0.969)\end{array}$ & $\begin{array}{r}-0.018 \\
(0.903)\end{array}$ & $\begin{array}{r}-0.016 \\
(0.891)\end{array}$ & $\begin{array}{r}-0.037 \\
(0.756)\end{array}$ & $\begin{array}{r}-0.133 \\
(0.304)\end{array}$ \\
\hline Foreign $\times M P$ & & & & & $\begin{array}{r}-0.036 \\
(0.532)\end{array}$ \\
\hline Foreign $\times M P \times$ Crisis & & & & & $\begin{array}{r}-0.276^{*} \\
(0.053)\end{array}$ \\
\hline$R^{2}$ & 0.255 & 0.259 & & 0.233 & 0.259 \\
\hline Observations & 2,613 & 2,613 & 2,613 & 2,927 & 2,613 \\
\hline
\end{tabular}

Notes: 1) p-values are in parentheses. ${ }^{* * *}$ : significant at $1 \%$ level, **: significant at $5 \%$ level, *: significant at $10 \%$ level, Standard errors are corrected for heteroscedasticity and clustered at bank level to control for the effects of residual autocorrelation.

2) Column (1): baseline results in Table 6, Column (2): Include interaction terms between MP and bank characteristics, Column (3): Random effects estimator is adopted, Column (4): Include all observations (no outlier removal procedure), Column (5): Include Foreign and its interaction terms with MP and Crisis.

markets. Overall, our results are important in that they document an impact of globalization operating amongst a group of Asian banks not hitherto studied. The results also demonstrate the potential for spillover effects from monetary policy, as a contraction in one country is transmitted to countries in which foreign subsidiaries operate through subsidiary funding being redeployed to support lending in markets in which headquarters operate. 


\section{References}

Cetorelli, N., Goldberg, L. S. (2011). Global banks and international shock transmission: Evidence from the crisis. IMF Economic Review, 59 (1), 41-76.

Cetorelli, N., Goldberg, L. S. (2012a). Banking globalization and monetary transmission. The Journal of Finance, 67 (5), 1811-1843.

Cetorelli, N., Goldberg, L. S. (2012b). Follow the money: Quantifying domestic effects of foreign bank shocks in the great recession. American Economic Review: Papers \& Proceedings, $102(3), 213-218$.

Cetorelli, N., Goldberg, L. S. (2012c). Liquidity management of U.S. global banks: Internal capital markets in the great recession. Journal of International Economics, 88 (2), 299- 311.

Cetorelli, N., Goldberg, L. S. (2016). Organizational complexity and balance sheet management in global banks. National Bureau of Economic Research.

Correa, R., Goldberg, L. S., Rice, T. (2014). Liquidity risk and US bank lending at home and abroad. National Bureau of Economic Research.

Jeon, B. N., Olivero, M. P., Wu, J. (2013). Multinational banking and the international transmission of financial shocks: Evidence from foreign bank subsidiaries. Journal of Banking \& Finance, 37 (3), 952-972.

Jeon, B. N., Wu, J. (2014). The role of foreign banks in monetary policy transmission: Evidence from Asia during the crisis of 2008-9. Pacific-Basin Finance Journal, 29, 96-120.

Nickell, S. (1981). Biases in dynamic models with fixed effects. Econometrica, 1417-1426.

Wu, J., Luca, A. C., Jeon, B. N. (2011). Foreign bank penetration and the lending channel in emerging economies: Evidence from bank-level panel data. Journal of International Money and Finance, 30 (6), 1128-1156.

Annual Report 2016 (2017), Hong Kong Monetary Authority.

Monetary Policy Operations in Singapore (2013), Monetary Authority of Singapore. 